https://nv.nltu.edu.ua

\title{
ДОСЛІДЖЕННЯ ВПЛИВУ БАРВНИКІВ І ТЕРМОДЕРЕВИНИ НА ЕКСПЛУАТАЦІЙНІ ХАРАКТЕРИСТИКИ ЗАХИСНО-ДЕКОРАТИВНИХ ПОКРИТТІВ ДЕРЕВИНИ
}

\begin{abstract}
Проаналізовано важливий етап технологічного процесу створення захисно-декоративного покриття деревини забарвлення. Поверхневому забарвленню зазвичай підлягають деталі та вузли, а також меблеві і столярні вироби у зібраному вигляді, під час останньої стадії виготовлення виробів. Унаслідок поверхневого забарвлення виявляється і підкреслюється текстура, притаманна саме цій деревині, імітуються цінні декоративні породи, підсилюється тон забарвлення. Встановлено, що на сьогодні великого застосування набули підфарбовані лакофарбові матеріали та барвники, розчинні в органічних розчинниках. Їх застосування дає змогу уникнути підняття ворсу, яке відбувається під час використання розчинів барвників і протрав. Проте з'ясовано, що основним недоліком поверхневого забарвлення є: невелика глибина проникнення забарвлюючого розчину в деревину, при цьому у процесі експлуатації виробу можливе його часткове або повне видалення. Відомо, що новинкою серед глибинного забарвлення є зміна кольору деревини під дією високої температури. Оброблення деревини під дією температури отримало назву "термооброблення". А деревина, яка підлягала обробленню - "термодеревина". Термодерево $є$ натуральним, абсолютно екологічно чистим, матеріалом. Термодерево інноваційний продукт сучасних технологій, який отримують у процесі оброблення дерева під дією високої температури $\left(140-240{ }^{\circ} \mathrm{C}\right)$ без застосування хімічних компонентів. Процес термооброблення надає деревині нові властивості: поверхня деревини не пориста, а щільна, що значно знижує здатність дерева вбирати вологу. У процесі термооброблення деревина змінює колір на коричневий відтінок, інтенсивність якого змінюється залежно від температури оброблення. Зміна кольору не поверхнева, а наскрізна, що добре видно на зрізі. Це дає змогу використовувати термодеревину для підлогового покриття. Встановлено, що матеріали та вид оброблення деревини, для зміни іiі забарвлення, може впливати на експлуатаційні та декоративні показники лакофарбових покриттів під час опорядження. Досліджено вплив різних видів забарвлення деревини на підставі фізико-механічні і декоративні властивості захисно-декоративних покриттів, створених поліуретановим й алкідним лаком, які найчастіше використовують для опорядження меблів і столярних виробів. Визначено, що температура оброблення термодеревини впливає на такі важливі характеристики, як товщина і твердість покриттів, які відповідають за експлуатаційні властивості виробу. Встановлено, що термічне оброблення деревини за температури, вищої ніж $140-160{ }^{\circ} \mathrm{C}$, знижує твердість і товщину плівки лакофарбового покриття. Отримані експериментальні дослідження свідчать про те, що температура оброблення деревини повинна не перевищувати допустимих меж для отримання якісного продукту.
\end{abstract}

Ключові слова: деревна підкладка; барвник; протрава; термодеревина; лакофарбовий матеріал; плівка; покриття; товщина; твердість; блиск.

\section{Вступ}

Запаси деревини, які мають багату і виразну текстуру, недостатні і вартість цієї деревини досить висока. Тому у виробництві меблевих і столярно-будівельних виробів широко застосовують імітацію деревини малодекоративних порід під деревину цінних порід. Одним із методів імітації може бути поверхневе та глибоке забарвлення. Забарвлювати деревину можна барвниками, протравами, морилками, які є давно відомими, однак ці методи мають низку істотних недоліків щодо вимиван- ня, стирання, світлостійкості та глибини проникнення кольору.

За останні роки було розроблено метод зміни забарвлення деревини термічною обробкою. Відомо, що під час термічного оброблення деревини без доступу повітря за температури, вищої ніж $120^{\circ} \mathrm{C}$, вона змінює свій колір. На інтенсивність забарвлення впливає температура і час оброблення. Зміна кольору деревини пов'язана із хімічно-фізичними перетвореннями, які відбуваються під час термічного оброблення із складовими компонентами деревини. Однак така деревина, не захищена

\section{Інформація про авторів:}

Яремчук Лариса Анаторіївна, д-р техн. наук, професор, кафедра технології меблів та виробів з деревини. Email: larysa.yaremchuk@gmail.com

Кушпіт Андрій Степанович, канд. техн. наук, доцент, кафедра технології меблів та виробів з деревини. Email: larysa.yaremchuk@gmail.com

Кобринович Михайло Степанович, канд. фіз.-мат. наук, доцент, кафедра математики і фізики. Email: muchaylokobrynovuch@ukr.net

Цитування за ДСтУ: Яремчук Л. А., Кушпіт А. С., Кобринович М. С. Дослідження впливу барвників і термодеревини на експлуатаційні характеристики захисно-декоративних покриттів деревини. Науковий вісник НлтУ України. 2021, т. 31, № 3. С. 89-93.

Citation APA: Yaremchuk, L. A., Kushpit, A. S., \& Kobrynovych, M. S. (2021). Study of the effect of dyes and thermal wood on the performance characteristics of protective and decorative coatings of wood. Scientific Bulletin of UNFU, 31(3), 89-93. https://doi.org/10.36930/40310314 
від впливу зовнішніх факторів, може зазнавати руйнування, захистом від якого слугує опорядження лакофарбовими матеріалами.

Вплив різних барвників на деякі фізико-механічні властивості на межі підкладка - лакове покриття вивчали різні вчені впродовж багатьох років. Проте вплив ЛФМ під час формування плівки на оброблених термічним методом підкладках, а також фізико-механічні властивості отриманих покриттів і їх порівняння з наявними класичними методами забарвлення деревини на сьогодні, практично, не вивчені.

Детальних систематичних досліджень фізико-механічних і декоративних характеристик плівок на підкладках, утворених різними методами забарвлення, не здійснювали. Тому вивчення впливу забарвленої підкладки на якісні показники плівки мають певний науковий і практичний інтерес.

Об'єкт дослідження - забарвлення деревини різними видами барвників.

Предмет дослідження - якісні характеристики забарвленої деревини різними видами барвників, що дасть змогу встановити деякі фізико-механічні та декоративні властивості захисно-декоративних покриттів.

Мета роботи - дослідження фізико-механічних i декоративних властивостей захисно-декоративної плівки, сформованої на забарвленій деревині різними методами (барвниками, протравами і термічно).

Для досягнення зазначеної мети визначено такі основні завдання дослідження:

1. Проаналізувати питання на підставі огляду літературних джерел, для проведення порівняльних досліджень впливу забарвлення деревної підкладки на експлуатаційні показники захисно-декоративних покриттів.

2. Експериментально дослідити вплив методів і видів забарвлення деревних підкладок та товщину плівки, за однакової витрати лакофарбових матеріалів, іiї твердість та блиск.

3. Обгрунтувати вибір забарвлюючих речовин і методів термічного забарвлення деревини для отримання якісних захисно-декоративних покриттів деревини.

4. Провести випробування фізико-механічних і декоративних показників плівки забарвленої деревної підкладки для виявлення якісних характеристик покриття за різних методів забарвлення.

Наукова новизна отриманих результатів дослідження - розроблено методику визначення впливу видів забарвлення деревини на підставі експлуатаційних властивостей лакофарбових плівок.

Практична значущість результатів дослідження результати експериментальних досліджень можна використати під час створення захисно-декоративних покриттів деревини, які потребують зміни кольору різними методами забарвлення, що дасть змогу отримувати якісні вироби загалом.

Аналіз літературних джерел та публікацій. Декоративні властивості природної деревини не завжди повністю відповідають вимогам споживачів виробів 3 неї. Одним із методів покращення декоративності деревини без зміни ii текстури є підсилення або зміна кольору. Колір, блиск і текстура деревини належать до декоративних характеристик деревини, яка дає змогу розпізнати якісні відмінності випромінювання, що зумовлені відмінністю спектрального складу.
Колір будь-якого матеріалу виражається математично в кількісному і якісному співвідношеннях 3 допомогою рівняння, що зв'язують основні координати кольору, тобто:

$$
\left\{\begin{array}{l}
R=0,7347 X+0,2653 Y+0,000 Z \\
G=0,2788 X+0,7174 Y+0,0088 Z \\
B=0,1655 X+0,0089 Y+0,8246 Z
\end{array}\right.
$$

де: $R, G, B$ - монохроматичні випромінювання із довжиною хвилі відповідно $\lambda=700 ; 546,1 ; \lambda=435,8$ Нм, тобто червоного (Red), зеленого (Green) і синього (Blue) кольорів [1]; $X, Y, Z$ - умовні кольори.

Отже, колір деревини Ц можна описати рівнянням

$$
\left\lfloor=r^{\prime} R+g^{\prime} G+b^{\prime} B,\right.
$$

де $r^{\prime}, g^{\prime}, b^{\prime}$ - координати кольору (коефіцієнти, які показують: скільки одиниць кожного основного кольору $R$, $G, B$ треба взяти, щоб отримати відповідний колір $L)$; $\left(r^{\prime} R\right),\left(g^{\prime} G\right),\left(b^{\prime} B\right)$ - складники кольору.

Згідно 3 дослідженнями $\quad$ О. П. Божка [2] та Б. Н. Уголєва [13], кольоровий тон основних вітчизняних і зарубіжних порід знаходився в області спектра 0,5775 (в'яз) ...0,599 (червоне дерево) мкм, що відповідає жовтому і оранжевому інтервалам спектра, а чистота кольору - в межах $18 \%$ (горіх далекосхідний) ... $62 \%$ (клен "пташине око"), яскравість - 19\% (горіх кавказький) ... 78 \% (в'яз: заболонь).

Отже, як випливає з наведеного вище, контроль і оцінювання кольору досі здійснюють, переважно, шляхом візуального спостереження кольору вимірювального об'єкта і зіставлення з еталоном. Такий спосіб визначення кольору є суб'єктивним, бо залежить від самого спостерігача (його фізичного і психологічного стану, втоми й адаптації ока і т.ін.), умов опромінення та довкільного середовища при кольорових порівняннях і т.ін.

Для зміни кольору деревини найчастіше застосовують поверхневе забарвлення, яке набуло найширшого застосування у меблевому виробництві [4]. Це пояснюють його відносно високою продуктивністю, застосуванням нескладного і недорогого обладнання, простотою здійснення технологічних процесів, придатністю майже для всіх порід деревини [8]. Для поверхневого забарвлення використовують водорозчинні та органорозчинні барвники, протрави, морилки, поронбейци.

Основним недоліком поверхневого забарвлення $\epsilon$ невелика глибина проникнення забарвлюючого розчину в деревину, тому під час експлуатації виробу можливе його часткове або повне видалення [12]. Новинкою серед глибинного забарвлення є зміна забарвлення деревини під дією високої температури. Термодеревина $є$ натуральним, абсолютно екологічно чистим, матеріалом [5].

Термодеревина - інноваційний продукт сучасних технологій, який отримують у процесі оброблення дерева паром високої температури (140-240 $\left.{ }^{\circ} \mathrm{C}\right)$ без застосування хімічних компонентів. Процес термооброблення надає деревині нових властивостей. Наприклад, термооброблена поверхня деревини не пориста, а щільна, що значно знижує здатність дерева вбирати вологу з повітря (на 30-90 \% залежно від температури і часу сушіння). У процесі термооброблення деревина змінює колір, змінюючи його на коричневий відтінок, залежно від температури. Зміна кольору не поверхнева, а наскрізна, що добре видно на зрізі $[5,6]$. 
Враховуючи декоративні властивості деревини i можливості зміни іiі властивостей унаслідок забарвлення, у роботі виконано дослідження впливу забарвлення барвників на деякі властивості опоряджених поверхонь.

Матеріали та методи дослідження. На підставі поставлених вище завдань і з урахуванням аналізу розглянутих наукових джерел i теоретичних посилань, встановлена необхідність експериментального вивчення деяких питань: визначення товщини та блиску лакової плівки; визначення твердості опорядженої деревини залежно від виду забарвленої підкладки; визначення адгезійної міцності опорядженої деревини залежно від виду забарвленої підкладки. Дослідження проводили із застосуванням приладів і пристосувань згідно з державними стандартами на здійснення цих експериментів.

Для досліджень застосовували підкладки із деревини дуба, оброблені термічно за температури 140, 180, $220{ }^{\circ} \mathrm{C}$. Забарвлені поверхні опоряджували лаками: поліуретановим "Паркетті Яся" (Польща) та алкідним ПФ-283. Для забарвлення використовували забарвлюючі речовини: барвник водорозчинний вишня (ТУУ 25101682.003-2001), барвник органорозчинний горобина (ТУУ 25101682.003-2001), протрава купорос залізний $\mathrm{Fe}_{2} \mathrm{SO}_{4} 5 \%$ (ГОСТ 6981-75), протрава $\mathrm{K}_{2} \mathrm{Cr}_{2} \mathrm{O}_{7}$ (ГОСТ 6981-75, протрава $\mathrm{CuCl}_{2}$ (ГОСТ 6981-75).

\section{Результати дослідження та їх обговорення}

Важливим показником, який відповідає за експлуатаційні властивості захисно-декоративного покриття, а відповідно за довговічність виробу, є товщина лакофарбової плівки.

Для виміру товщини лакової плівки використовували такі зразки:

- № 1 підкладка дуба, зафарбована водорозчинним барвником;

- № 2 підкладка дуба, зафарбована органорозчинним барвником;

- № 3 підкладка дуба, зафарбована протравою $\mathrm{Fe}_{2} \mathrm{SO}_{4} 5$ \%;

- № 4 підкладка дуба, зафарбована протравою $\mathrm{K}_{2} \mathrm{Cr}_{2} \mathrm{O}_{7}$;

- № 5 підкладка дуба, зафарбована протравою $\mathrm{CuCl}_{2}$;

- № 6 підкладка дуба, термічно оброблена $T=140{ }^{\circ} \mathrm{C}$, упродовж 4 год;

- № 7 підкладка дуба, термічно оброблена $T=180{ }^{\circ} \mathrm{C}$, упродовж 8 год;

- № 8 підкладка дуба, термічно оброблена $T=220{ }^{\circ} \mathrm{C}$, упродовж 4 год.

Після висихання розчинів барвників поверхню зразків покрили лаками поліуретановим "Паркетті Яся" (Польща) та алкідним ПФ-283 в один шар 3 витратою 130 г/м². Після висихання лакових покриттів виконали заміри товщини захисно-декоративної плівки з допомогою мікроскопу МИС-11. Отримані результати подано на рис. 1.

Результати досліджень товщини захисно-декоративних покриттів показали, що за однакових витрат лакофарбових матеріалів товщина плівки, нанесеної на деревину, забарвлену класичними барвниками, є значно вища, ніж у разі нанесення на термодеревину.

Це може бути пов'язане із багатьма факторами, які впливають на товщину плівки: вміст сухих речовин у лаковій композиції (сухий залишок), щільність підкладки, яка зумовлює різну глибину проникнення ЛФМ, наявність попереднього грунтування (заповнення пор деревини), а також шорсткість підкладки. Проте для цього випадку, варто зазначити, що для однакових умов (підкладка, вид ЛФМ, витрата на одиницю площі) максимальна товщина лакової плівки спостерігається на підкладці, яка термічно оброблена за температури $140{ }^{\circ} \mathrm{C}$. Поясненням цього $\epsilon$ те, що за такої температури відбувається ущільнення деревини, а деструкція не спостерігається. Із підвищенням температури забарвлення стає інтенсивнішим, а товщина плівки стрімко зменшується, що свідчить про початок деструкції деревини, а відповідно - збільшується поглинання ЛФМ.

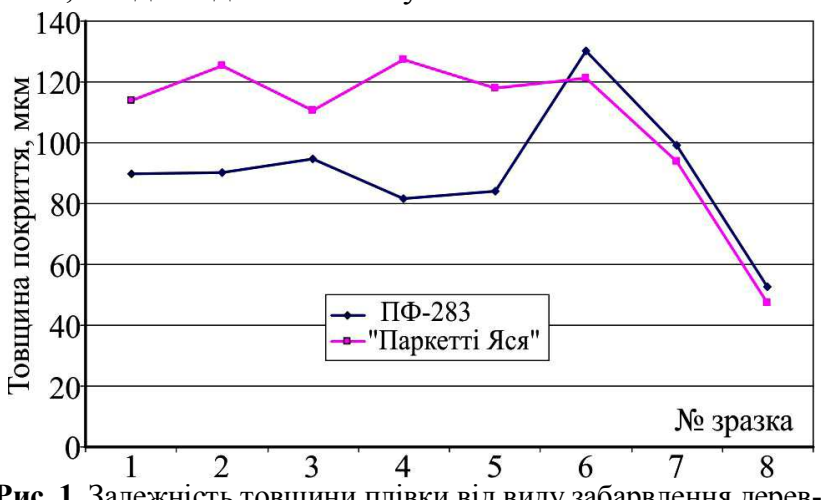

Рис. 1. Залежність товщини плівки від виду забарвлення деревної підкладки

Опір поверхневих шарів матеріалу місцевим деформаціям забезпечує твердість покриття. Твердість плівки відповідає цілісності поверхні лакофарбового покриття при механічних діях (ударі, подряпині, тиску) і визначається когезійними властивостями плівкоутворювача [14].

Для визначення твердості покриттів на підкладках, забарвлених різними видами барвників, використовували зразки, наведені раніше. Твердість визначали за методом олівця. Визначення твердості плівок за допомогою умовних значень твердості за олівцем (ГОСТ Р 54586-2011 ИСО 15184:1998). Для наочності отриманих результатів наведено табл. 1 , де найнижчій твердості за олівцем 5В буде відповідати числове значення 1, а найвищій $5 \mathrm{H}-12$.

Табл. 1. Результати заміни твердості покриттів за олівцем на числове умовне значення

(згідно з ГОСТ Р 54586-2011 та ИСО 15184:1998)

\begin{tabular}{|c|c|c|c|c|c|c|c|c|c|c|c|c|}
\hline $\begin{array}{c}\text { Шкала } \\
\text { твердості } \\
\text { олівця }\end{array}$ & $5 \mathrm{~B}$ & $4 \mathrm{~B}$ & $3 \mathrm{~B}$ & $2 \mathrm{~B}$ & $\mathrm{~B}$ & $\mathrm{HB}$ & $\mathrm{F}$ & $\mathrm{H}$ & $2 \mathrm{H}$ & $3 \mathrm{H}$ & $4 \mathrm{H}$ & $5 \mathrm{H}$ \\
\hline $\begin{array}{c}\text { Числова } \\
\text { умовна } \\
\text { одиниця }\end{array}$ & 1 & 2 & 3 & 4 & 5 & 6 & 7 & 8 & 9 & 10 & 11 & 12 \\
\hline
\end{tabular}

Твердість за олівцем дає змогу порівнювати показники на деревинних підкладках, на відміну від показника твердості за маятниковим твердоміром М-3, де твердість плівки заміряють тільки на скляній підкладці. Для отримання наближених до реальності результатів твердість визначали для покриттів, сформованих із поліуретанового лаку "Паркетті Яся" та алкідного лаку ПФ283. Результати експериментальних досліджень наведено у табл. 2.

Визначення твердості плівки, як одного із найважливіших експлуатаційних показників захисно-декоративних покриттів, показало, що в разі використання підкладки, забарвленої барвниками, протравами і термічного оброблення деревини за температури, не вищої ніж $140{ }^{\circ} \mathrm{C}$, твердість відповідає експлуатаційним вимогам покриттів. Однак зі збільшенням температури оброблення деревини твердість плівки різко знижується, 
що підтверджує висновки про деструкцію підкладки [11].

Табл. 2. Результати визначення твердості лакофарбових покриттів, виражені в умовних одиницях

\begin{tabular}{|c|c|c|c|}
\hline $\begin{array}{c}\text { № } \\
\text { зразка }\end{array}$ & $\begin{array}{c}\text { Вид матеріалу } \\
\text { покриття }\end{array}$ & $\begin{array}{c}\text { Твердість за } \\
\text { олівцем }\end{array}$ & $\begin{array}{l}\text { Твердість, } \\
\text { у.о. }\end{array}$ \\
\hline \multirow{2}{*}{1} & "Паркетті Яся" & $\mathrm{HB}$ & 6 \\
\hline & ПФ-283 & $\mathrm{H}$ & 8 \\
\hline \multirow{2}{*}{2} & "Паркетті Яся" & $\mathrm{B}$ & 5 \\
\hline & ПФ-283 & $2 \mathrm{H}$ & 9 \\
\hline \multirow{2}{*}{3} & "Паркетті Яся" & $\mathrm{HB}$ & 6 \\
\hline & ПФ-283 & $\mathrm{H}$ & 8 \\
\hline \multirow{2}{*}{4} & "Паркетті Яся" & $\mathrm{HB}$ & 6 \\
\hline & ПФ-283 & $\mathrm{H}$ & 8 \\
\hline \multirow{2}{*}{5} & "Паркетті Яся" & $\mathrm{HB}$ & 6 \\
\hline & ПФ-283 & $2 \mathrm{H}$ & 9 \\
\hline \multirow{2}{*}{6} & "Паркетті Яся" & $\mathrm{HB}$ & 6 \\
\hline & ПФ-283 & $2 \mathrm{H}$ & 9 \\
\hline \multirow{2}{*}{7} & "Паркетті Яся" & $3 \mathrm{~B}$ & 3 \\
\hline & ПФ-283 & $\mathrm{HB}$ & 6 \\
\hline \multirow{2}{*}{8} & "Паркетті Яся" & $5 \mathrm{~B}$ & 1 \\
\hline & ПФ-283 & $3 \mathrm{~B}$ & 3 \\
\hline
\end{tabular}

Захисно-декоративні покриття визначаються не тільки фізико-механічними характеристиками плівки, але і декоративними показниками. Одним із показників, які визначають декоративні властивості, а водночас залежать від товщини плівки, є блиск покриття. Блиск виявляється у здатності направлено відбивати падаючий світловий потік від поверхні плівки [7].

Визначення блиску покриття проводили 3 допомогою приладу ФБ-2 на попередньо забарвлених різними видами барвників підкладках, а також на термодеревині, які були опоряджені зазначеними вище лакофарбовими матеріалами. Результати експериментальних досліджень подано графічними залежностями (рис. 2).

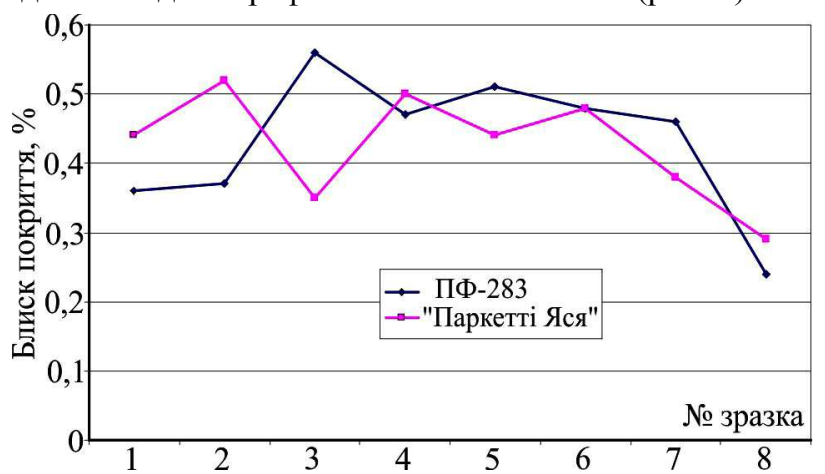

Рис. 2. Залежності впливу забарвлення деревної підкладки на

блиск захисно-декоративного покриття

Результати досліджень довели, що блиск покриттів сильно розсіюється (див. рис. 2). Згідно з даними експериментальних досліджень, зі збільшенням товщини лакофарбового покриття, блиск також збільшується у ЛФМ одного виду плівкоутворювача. Оскільки лак "Паркетті Яся" містить у своєму складі матуючі добавки, аналіз блиску покриттів доцільно проводити на глянцевому лаку ПФ-283. За результатами дослідження виявлено, що найвищого блиску можна досягти в разі використання підкладки, забарвленої протравою. Це пояснюють тим, що протрави (розчини солей металів) забарвлюють внаслідок хімічної реакції солей металів 3 дубильними і не вуалюють текстуру деревини. ЛФМ покриття, на поверхні деревини, забарвленої протравами, має вищий показник заломлення, ніж у покриттів, забарвлених іншими барвниками. Очевидно, це свідчить про те, що під час дослідження блиску за приладом ФБ-2 потрібно враховувати коефіцієнт породи, а під час нанесення протрави дуже чітко відтворюється текстура і колір деревини. Під час термічного оброблення спостерігається деяке вуалювання текстури деревини, яке має чіткий вплив на блиск поверхні захисної плівки.

Для матових ЛФМ основним показником буде глибина матовості. Дослідження захисно-декоративних плівок на підставі матового лаку "Паркетті Яся" на забарвлених різними барвниками підкладках, підтвердило, що найбільший показник матовості покриття відповідає термічно забарвленій (за температури $220^{\circ} \mathrm{C}$ ) підкладці. Отримані дані підтверджують попередній висновок про вуалювання текстури деревини та іiї деструкції за підвищення температури оброблення деревини.

Обговорення результатів дослідження. Аналіз літературних джерел з цього дослідження показав, що забарвлення деревини різними видами барвників мало вивчене і потребує подальших експериментальних досліджень і висновків, якими методами і матеріалами краще забарвлювати деревинну підкладку, щоб досягти належної якості захисно-декоративного покриття [4].

Проведені та отримані результати експериментальних досліджень показали, що товщина захисно-декоративного покриття, створеного поліуретановим лаком, $\epsilon$ більшою від товщини плівки на підставі алкідного лаку незалежно від виду забарвлення підкладки, оскільки відомо, що сухий залишок поліуретанових композицій $\epsilon$ вищий, ніж в алкідних ЛФМ [4]. Проте для деревини, у якої змінювався колір залежно від зміни температури оброблення, товщина плівки істотно підвищилась для деревини, обробленої за температури $140{ }^{\circ} \mathrm{C}$, i різко знизилась для деревини, обробленої за 180 та $240{ }^{\circ} \mathrm{C}$. Це пояснюють тим, що спочатку під час термооброблення деревина ущільнюється, а 3 підвищенням температури відбувається іiі деструкція [5]. Такі висновки можна зробити під час визначення твердості покриття. Дослідження підтвердили, що із підвищенням температури термооброблення деревини, твердість сухої плівки лакофарбового покриття знижується.

Дослідження декоративних властивостей лакофарбових покриттів підтвердили, що найкращі показники блиску (матовості) забезпечують захисно-декоративні покриття на деревині, забарвленій протравами. Відомо, що протрави зовсім не вуалюють текстуру деревини та утворюють кольорові і прозорі забарвлення 3 найбільшим для забарвленої деревини коефіцієнтом заломлення світла, що надалі впливає на блиск лакофарбової плівки для прозорих покриттів деревини [10].

\section{Висновки}

1. Обгрунтовано доцільність і актуальність досліджень 3 вивчення впливу барвників і термічно обробленої підкладки деревини на фізико-механічні властивості лакофарбових покриттів.

2. Експериментальними дослідженнями підтверджено, що товщина плівки і твердість покриття істотно залежить від щільності підкладки, їі твердості та хімічного складу у поверхневому шарі.

3. Доведено, що на термічно забарвлених підкладках основні фізико-механічні показники змінюються неістотно за температури термічного оброблення не вищої 
ніж $140{ }^{\circ} \mathrm{C}$. Підвищення температури призводить до початку деструкції деревини, а відповідно - до зміни іiі щільності та інших фізико-механічних показників деревини, які істотно впливають на експлуатаційні характеристики захисно-декоративної плівки.

4. Дослідження декоративних властивостей покриттів, забарвлених різними матеріалами і методами підкладок, підтвердили зв'язок між фізико-механічними характеристиками плівок, створених на деревині, і методами ії забарвлення.

\section{References}

1. Beliaev, E. Iu., Ermolin, V. N., Meleshko, A. V., \& Sokolov, V. P. (1999). Krashenie drevesiny. Khimiia rastitelnogo syria, 2, 518. [In Russian].

2. Bozhok, O. P., \& Vintoniv, I. S. (1992). Derevynoznavstvo $z$ osnovamy lisovoho tovaroznavstva: navch. posibnyk. Kiev: NMK VO, 320 p. [In Ukrainian].

3. Chernenko, S. A., \& Bernat, A. I. (1968). Oblagorazhivanie drevesiny krasiteliami metodom tortcovoi propitki pod davleniem. Moscow: Nauka, 18 p. [In Russian].

4. Dzhordzh Prieto, \& Iurgen Kine Drevesina. (2008). Obrabotka i dekorativnaia otdelka; (Poliakovoi, M. V. Trans. from German). Moscow: Peint-Media, 392 p. [In Russian].

5. Finnish Thermowood Association. (2003). Thermowood Handbook. Wood Focus Oy. Helsinki, Finland, 66 p.
6. Huber, Yu. M., \& Mytsko, V. M. (2012). Eksperymentalne doslidzhennia rozbukhannia termoderevyny buka. Scientific Bulletin of UNFU, 22(13), 131-136. [In Ukrainian].

7. Khloptunova, IU. V., Meleshko, A. V., et al. (2002). Blesk prozrachnykh mnogosloinykh pokritii na drevesine. Tekhnologiia i oborudovanie derevoobrabatyvaiushhikh proizvodstv: Mezhvuz. sb. nauch. tr. St. Petersburg: SPb LTA, 78-85. Retrieved from: http://www.stroyportal.ru/articles/1450.html. [In Russian].

8. Michaelsen, H., \& Buchholz, R. (2006). Vom Faerben des Holzes - Holzbtizen von der Antike bis in die Gegenwart, Michael Inhof Verlag $\mathrm{GmbH}$ und Co. KG, Petersberg,

9. Onegin, V. I., \& Leonovicha, A. A. (Ed.). (1983). Formirovanie lakokrasochnykh pokrytii drevesiny. Leningrad: Izd-vo Leningr. un-ta, 148 p. [In Russian].

10. Onegin, V. N., \& Tcoi, IU. I. (1982). Tekhnologiia otdelki drevesiny. Uchebnoe posobie. Leningrad: Nauka, 79 p. [In Russian].

11. Prudnikov, P. G., Goldberg, E. E., \& Kordonskaia, B. K. (1982). Spravochnik po otdelke mebeli, 255 p. [In Russian].

12. Sappel, M. (2005). Holzbtizen - Ein Vergleich von historischen und modernen Beizen, Vortraege am Mittwoch, Informationsblatt 30, Freilichtmuseuum Hessenpark. (Date of application: 04.05.2005)

13. Ugolev, B. N. (2007). Drevesinovedenie i lesnoe tovarovedenie: uchebnik. Moscow: GOU VPO MGUL, 351 p. [In Russian].

14. Zhukov, E. V., \& Onegin, V. N. (1993). Tekhnologiia zashhitnodekorativnykh pokrytii drevesiny i drevesnykh materialov: uchebnik dlia vuzov. Moscow: Lesnaia promyshlennost. 420 p. [In Russian].

L. A. Yaremchuk, A. S. Kushpit, M. S. Kobrynovych Ukrainian National Forestry University, Lviv, Ukraine

\section{STUDY OF THE EFFECT OF DYES AND THERMAL WOOD ON THE PERFORMANCE CHARACTERISTICS OF PROTECTIVE AND DECORATIVE COATINGS OF WOOD}

The paper considers painting as an important stage of the technological process of creating a protective and decorative coating of wood. Components and joinery, as well as furniture and carpentry in assembled form, are usually subjected to surface painting during the last stage of product manufacturing. As a result of surface coloring the texture inherent in this wood is revealed and emphasized, valuable decorative species are imitated, the tone of coloring is amplified as well. Our research has revealed that currently tinted paints and dyes soluble in organic solvents are widely used. Their application allows avoiding the rise of pile, which occurs when using solutions of dyes and pickles. The main disadvantage of surface painting is as follows: the small depth of penetration of the paint solution into the wood, that during the processing of the product it is possible to partially or completely remove it. The change in color of the wood under the effect of high temperature is supposed to be the deep colour novelty. A new type of wood processing by temperature effect is called heat treatment. The wood to be treated is thermowood. Thermowood is a natural, completely environmentally friendly material. Thermowood is an innovative product of modern technologies, which is obtained in the process of treating wood with high temperature steam $\left(140-240{ }^{\circ} \mathrm{C}\right)$ without the use of chemical components. The heat treatment process gives the wood the following new properties: the wood surface is not porous, but dense, which significantly reduces the ability of wood to absorb moisture. In the process of heat treatment, the wood changes color to a brown hue, the intensity of which varies with the processing temperature. The color change is not superficial, but through, which is clearly visible in the cut. This allows using thermal wood for flooring. Our research investigates the influence of different types of wood color on the main physical and mechanical and also decorative properties of protective-decorative coatings created with polyurethane and alkyd varnish, which are mostly used for finishing furniture and joinery. The temperature of thermal wood processing is found to affect such important indicators as the thickness and hardness of the coatings, which are responsible for the performance of the product. Wood processing by heat treatment at temperature higher than $140-160^{\circ} \mathrm{C}$ reduces hardness and thickness of varnish covering film. The results of our experimental studies indicate that the temperature of wood processing should not exceed the permissible limits in order to obtain a quality product.

Keywords: wood substrate; pickled dye; thermowood; paint material; film; coating; thickness; hardness; gloss. 